\title{
OPTIMERINGSEKSPERIMENTER \\ Postkritiske perspektiver på monitorering og evaluering i en miljøorganisation
}

\section{BRIT ROSS WINTHEREIK OG CASPER BRUUN JENSEN}

I vestlige samfund er det blevet almindelig praksis at dokumentere snart sagt enhver aktivitet - fra børns læsefærdigheder til kroppens fødeindtag og organisationers mange forskelligartede ,præstationer“ - og gøre den til genstand for evaluering. Ifølge sociologen Michael Power finder evalueringerne sted inden for så mange områder, at man kan tale om en evalueringseksplosion (audit explosion) (jf. Jensen \& Winthereik 2013:121-47). Power argumenterer for, at evalueringer har fået en legitimerende og rituel funktion i det moderne samfund. Det vil i hans optik sige, at evalueringer i vid udstrækning udføres for deres egen skyld. Effekten af dem er således ikke nødvendigvis, at kvaliteten af det, der evalueres, højnes. Snarere, mener han, resulterer evalueringer ofte $\mathrm{i}$ en form for tillært uvidenhed (learned ignorance) (Power 1997:123).

Powers kritik fulgte i kølvandet på new public management-bølgen, som op gennem 1990'erne havde fået en enorm indflydelse på, hvordan offentlige institutioner blev ledet og styret. Formålet med new public management var at modernisere gennem en omfattende liberalisering: De stigende offentlige udgifter skulle med andre ord nedbringes, uden at kvaliteten og det oplevede serviceniveau blev sænket. Indførelsen af nye teknologier til dokumentation af arbejdet blev et vigtigt led i denne reformproces. Via en omfattende dokumentations- og evalueringspraksis skulle de enkelte aktiviteter synliggøres. Tanken var, at hvis aktiviteter blev synlige $i$ et stort sammenhængende system, kunne overflødige aktiviteter fjernes og hele sektoren gøres mere effektiv.

New public management (NPM) er således en paraplybetegnelse. Den dækker over mange forskellige ledelsesformer og redskaber til optimering af arbejdet. Overordnet trækker NPM på taylorismens tanke om, at der findes one best way for en organisation at udføre arbejdet på (Vikkelsø \& Vinge 2004). I NPM er det ledelsens ansvar at finde denne måde, og medarbejderens pligt at udføre den. På Frederick Taylors tid fandt man blandt andet frem til denne one best way gennem 
tidsmålinger. I dag er de metoder, der anvendes under NPM, mere forskelligartede. Grundlæggende trækker de dog på de samme ideer. Disse ideer ligger således også bag forestillingen om, at registrerings- og evalueringssystemer vil kunne strømline arbejdet $i$ offentlige institutioner. I det følgende vil vi beskæftige os med eksempler på sådanne systemer til optimering af arbejdsprocesser i en NGO.

Et af de væsentligste samfundsvidenskabelige kritikpunkter i forhold til NPM er, at evalueringsredskaber kun kan måle det, de allerede ved findes, og derfor aldrig vil kunne synliggøre noget nyt. Antropologiske kritikere fastholder, at de registrerings- og evalueringssystemer, der i dag er så udbredte, at det er svært at forestille sig et arbejdsliv uden dem, simplificerer en kompleks virkelighed. Denne kritik stiller skarpt på NPM's krav om optimering af organisatorisk performance og peger på denne tankegangs reduktive effekter (jf. Shore \& Wright 1997). Antropologer har imidlertid også en anden rolle at spille i forhold til NPM. Antropologer er i dag i vidt omfang med til at udføre de mange evalueringer, der er blevet en naturlig del af den organisatoriske hverdag. Når virksomheder som Antropologerne.com og Red Associates synliggør de „sociale“ eller ,adfærdsmæssige" aspekter af en praksis i forbindelse med en evaluering, deltager antropologisk viden og etnografiske færdigheder i optimeringen. ${ }^{1}$

I denne artikel, der fokuserer på monitorering og evaluering $\mathrm{i}$ den danske afdeling af en international miljøorganisation, som vi kalder NatureAid, ${ }^{2}$ stiller vi spørgsmålstegn ved nogle gængse kritiske forestillinger om standarder og optimering. Inspireret af Marilyn Stratherns analyser af afrapportering (accountability) som kulturel praksis (2000) viser vi, hvordan både redskaberne til optimering og det, de skal optimere, bliver til det, de er, gennem det praktiske arbejde med at optimere. Vores anvendelse af optimering som både empirisk og analytisk objekt bevirker, at vi kan sammenligne medarbejdernes synliggørelsesarbejde med antropologens. Strathern påpeger at evaluatoren:

kun [er] lidt anderledes end antropologen, der oversætter på tværs af kulturer. Antropologens analytiske kategorier (social struktur, kulturelle værdier, organisationsformer) omskaber en slags beskrivelse (folks selvopfattelser) til en anden og tilslører derved visse sandheder ved at afdække andre (Strathern 2000: 70 , vores oversættelse).

Vi viser, at den synliggørelse af forskellige former for virkelighed, der er forbundet med optimeringsarbejde, hviler på forudanelser og antydninger, der kan sammenlignes med antropologens synliggørelse af felten (jf. Pedersen \& Nielsen 2013; Dalsgaard \& Nielsen 2013).

Ligeledes er vi inspireret af Bruno Latours forsøg på at definere en samfundsanalyse, hvis præmis er en „fornyet" og eksperimentel empirisme snarere end kritik (Latour 2004). En sådan empirisme forefindes inden for STS-studier af 
standardisering, der har påvist de mangeartede konsekvenser, standarder har for organisationer og mennesker (Bowker \& Star 2000). Fællestrækket blandt disse tilgange er, at de ikke beror på en antagelse om, at monitorering og evaluering til syvende og sidst er "styringsteknologier“, der kun i begrænset omfang kan påvirkes af dem, de ,styrer“. I stedet giver indførelsen af sådanne teknologier anledning til uforudsigelige processer - eksperimenter i, hvad det kan betyde at optimere.

I de følgende afsnit beskriver vi, hvordan medarbejderne bruger evalueringsredskaber til at synliggøre deres erfaringer fra projektarbejde på en måde, der kan aktualisere dem $\mathrm{i}$ forhold til fremtidigt arbejde i organisationen. Vi viser, hvordan medarbejderne deltager $i$ at skabe vilkårene for deres egen praksis og dermed også for organisationens forandring. De indgår i optimeringseksperimenter.

\section{Terms of reference}

I løbet af 2011-2012 foretog vi feltarbejde i miljøorganisationen NatureAid. Feltarbejdet var del af et mere omfattende studie af partnerskaber og monitorering i udviklingsbistand (Jensen \& Winthereik 2013). Her undersøgte vi, hvilken rolle monitorerings- og evalueringsstandarder spillede for samarbejdsrelationer inden for og imellem NGO'er og andre partnere i udviklingsarbejde.

Vores udgangspunkt var en interesse for, hvordan Paris-erklæringens fordring om en højere grad af økonomisk og social ansvarlighed i udviklingsbistanden udmøntedes lokalt. ${ }^{3}$ Specifikt undersøgte vi den danske afdeling af NatureAid, som kort forinden havde modtaget en programbevilling fra Danida. Bevillingen udgjorde en relativt stor del af organisationens finansieringsgrundlag, og medarbejderne i det team, der laver ulandsarbejde, var derfor meget opmærksomme på at leve op til de krav om gennemsigtighed, der blev stillet fra Danidas side. Samtidig var de underlagt forskellige dokumentationskrav fra organisationens internationale netværk.

I denne kontekst studerede vi en række standarder: dokumenter til halv- og helårlig afrapportering, organisationens internationale „evalueringshjul“ og Danidas forskelligartede dokumentationskrav. Endvidere observerede vi medarbejderne i forbindelse med deres daglige aktiviteter og foretog in situ- og strukturerede interviews om monitorering og evaluering med medarbejdere på alle niveauer i organisationen. Winthereik deltog også i et 12 dage langt kontrolbesøg hos partnere i Vietnam.

Vores mulighed for at lave feltarbejde kom i stand efter en seks måneder lang forhandling, der indebar, at vi blev bedt om at formulere et sæt terms of reference, der beskrev, hvorledes vores undersøgelse ville bidrage til organisationens monito- 
rerings- og evalueringsarbejde. Den endelige version af dette dokument, stilet til organisationens bestyrelse, klargjorde, at vi ville vurdere dette arbejde og dele vores analyser med medarbejderne i to workshops. Vores eget formål med undersøgelsen var først og fremmest analytisk, men blev muliggjort af lovning om at deltage i ,intern læring“. Man kan således sige, at vores arbejde placerede sig midt imellem analyser af og for organisationer (Jensen \& Winthereik 2013: $31-51)$.

\section{At redde verden - med rapporter}

Under de indledende møder fik vi indtryk af, at medarbejderne var frustrerede over de mange dokumentationskrav. Særligt ærgrede det dem, at det arbejde, der blev lagt i monitorering og evaluering, ikke i nævneværdig grad gav anledning til intern organisatorisk læring. Denne frustration og ønsket om at ændre en fastlåst situation var formentlig en vigtig årsag til, at vi blev inviteret til at følge arbejdet blandt miljøkonsulenterne.

For at forstå hvilken rolle monitorering og evaluering spillede i organisationen er det relevant at nævne, at medarbejderne alle på forskellig vis var optaget af at „redde verden“. Det fremgår af flere interviews, at det at gøre en positiv forskel er en væsentlig motivation for at arbejde i netop denne organisation. Ønsket om at deltage i at redde verden blev også udtrykt på morgenmøder, der både havde karakter af informationsudveksling om igangværende projekter og kollektiv opbakning i forhold til deres forskellige udfordringer. Til trods for de gode intentioner kunne det dog være ganske svært for medarbejderne at vurdere, om de rent faktisk skabte positive forandringer. Det store spørgsmål var således, hvordan de bedst muligt kunne optimere deres viden om projekterne.

På den ene side er der ingen tvivl om, at medarbejderne tog afrapportering til Danida og til det internationale hovedkvarter alvorligt, både fordi levering af denne dokumentation er et formelt krav, og fordi disse rapporter formodes at bidrage til en afdækning af bistandens effektivitet på et makroplan. På den anden side oplevedes dette arbejde dog i store træk som noget, der skulle overstås, undtagen i det omfang rapporteringen også var gavnlig for medarbejderne selv. Som Kirsten fra ulandsteamet formulerede det:

Vi monitorerer i høj grad for os selv. Hvis vi bare skulle monitorere for at have det godt med Danida, ville vi ikke [gøre det]... de fem siders statusrapport, når man har arbejdet med det i mange år, kan godt være venstrehåndsarbejde. Det er mere for os selv. Fordi vi gerne vil lave nogle fede projekter; jeg vil virkelig gerne gøre en forskel (interview med NatureAid-medarbejder 2011). 
Fra samtaler med Kirsten og andre medarbejdere blev det efterhånden klart, at de anså den mest relevante del af monitorerings- og evalueringsarbejdet for at være de fælles refleksioner, der følger efter de forskellige afrapporteringer.

Men betydningen af disse diskussioner blegner i sammenligning med vigtigheden af det løbende arbejde med at vedligeholde relationer medarbejderne imellem og til deres partnere i de lande, hvor udviklingsprojekterne foregår. En anden medarbejder, Hanne, formulerede det sådan:

Det er ikke gennem standardiserede formater, jeg får information om, hvordan et projekt kører, det er ikke, når jeg får min progress report. Der er ved min løbende dialog og ved mine projektbesøg. Rapporterne er gode at have at falde tilbage på, men nogle standarder, hvor der står, det går sådan og sådan på input 1 , nej. Det substantielle, det er der, hvor man får en viden om det, som vi egentlig gerne vil nå for skatteborgernes penge. Hvad er det for en forskel, vi gerne vil gøre? Det får jeg ikke at vide fra dokumenterne, men fra andre kilder (interview med NatureAid-medarbejder 2011).

„Standardiserede formater" bruges til at påvise, at udviklingsarbejdet nytter noget. Imidlertid fortæller medarbejderen her om, hvordan arbejdets nytte fastslås fra andre kilder. ${ }^{4}$

I næste afsnit viser vi, hvordan medarbejderne i miljøorganisationen engagerer sig i udviklingen af standarder. Hensigten med dette engagement er ikke, at de lokale standarder fuldt skal erstatte de internationale, men at de forskellige redskaber kan sameksistere og dermed give et mere komplet billede af arbejdet. En anden hensigt er, at arbejdet med at designe og bruge evalueringsværtøjer vil skabe et rum for kollektiv refleksion og læring kollegaer imellem. De håber, at arbejdet med redskaberne kan bringe faglige og procesmæssige forskelligheder i spil.

\section{En standard genopfindes}

I forbindelse med en mailkorrespondance med Hanne, der arbejder med at implementere Danida-programmet, fik vi adgang til en række interne dokumenter, der indeholdt miljøorganisationens internationale standarder for styring af projekter og programmer (standards of project and programme management). Dokumentet beskriver en projektcyklus fra produktionen af den første projektbeskrivelse til den endelige evaluering. Der findes detaljer om en række delelementer såsom „generel praksis og antagelser“, „,definition“, ,design“, ,implementering“, ,analyse og tilpasning“ og „deling“. Standarderne er udformet ganske detaljeret, og de indbefatter et væld af guidelines inden for hvert område. Der er for eksempel 
standarder for ,at give og modtage feedback, udføre evalueringer og audits og promovere en læringskultur" (fremhævelser i original). ${ }^{5}$

Det er værd at bemærke, at det internationale hovedkontors standard vægter formelle, målbare præstationer og etableringen af en læringskultur. Den nævnte standard understreger for eksempel vigtigheden af uformel feedback og argumenterer for, at de formelle feedbackmekanismer altid bør suppleres med uformel kommunikation.

Selv om feedback i mange organisationer er begrænset til formelle performance reviews, foregår noget af den bedste feedback uformelt, hvis folk tager sig tid til at stille spørgsmål til deres kolleger og lytter til, hvad de har at sige (fremhævelser i original).

Dokumentets sidste standard beskriver altså skabelsen af en præstations- og læringskultur. Her understreges det, at såvel formel som uformel feedback bør være en del af organisationers rutiner og tankesæt. Formålet er at skabe praksisfællesskaber (Lave \& Wenger 1991), der kan handle på baggrund af detaljeret information.

I standards of project and programme management sameksisterer formel, kvantitativ monitorering og evaluering med promoveringen af procesorientering, kritisk analyse, sammenligning og narrative metoder. Vi er her tæt på en terminologi, der også findes inden for antropologisk forskning. Da flere af konsulenterne havde en baggrund $i$ antropologi eller andre samfundsvidenskaber, forestillede vi os da også, at sådanne standarder måtte være guld værd for dem. Standarden leverede både detaljerede guidelines og tabeller og opfordrede til at benytte såvel kvalitative som kvantitative data og metoder. Ikke desto mindre så vi den aldrig anvendt, og vi hørte den heller ikke omtalt i samtaler eller til møder mellem medarbejderne.

„Hvordan bruger I de internationale standarder i jeres daglige arbejde?“ spurgte vi Kirsten. Hun afviste blankt, at de skulle have nogen reel værdi. „Grundlæggende, “ sagde hun, ,,er de standarder alt for overordnede og ukonkrete. Der er ingen sammenhæng mellem deres krav og det, der giver mening for os at evaluere på.“ Selv om standarderne var gode til at måle visse ting, kunne de altså ikke bruges til at måle de ting, hun gerne ville vide noget om:

De kan bruges til at opsamle erfaringer på det, der kan måles. At der er kommet flere næsehorn. Men de kan ikke hjælpe os med at vise ændrede handlemønstre blandt dem, der er problemet for naturressourcerne (interview med NatureAidmedarbejder 2011).

Kirsten understreger flere gange, at problemet både er, at standarden er for detaljeret, og at den synliggør forkerte ting og derfor ikke rummer muligheden for 
at beskrive netop den slags kompleksitet, der er relevant for hende at forholde sig til. Den viden, hun er interesseret $i$, handler om forholdet mellem økonomisk udvikling og social forandring. Netop den relation, påpeger Hanne, er for kompleks til at blive rummet af en standard, der, efter hendes mening, fokuserer mest på det målbare. Det var just på den baggrund, at ulandsteamet i løbet af vores feltarbejde barslede med at genopfinde et sæt af interne evalueringsstandarder. Grunden til, at de skulle genopfindes, var, at de var faldet ud af den organisatoriske hukommelse på grund af omfattende nedskæringer og fyringer et par år tidligere.

Ifølge Hanne var formålet med at genskabe disse standarder at støtte medarbejderne i på en gang at, ,vurdere relevansen, nytteværdien og bæredygtigheden af udviklingsarbejde“. Disse kriterier blev anset for at være væsensforskellige fra de evalueringer af naturbeskyttelse, der fordres af eksterne organisationer. Et af de vigtigste kendetegn ved de hjemmelavede standarder er deres minimalisme. I modsætning til den omfattende og meget detaljerede dokumentation, der skal laves til Danida og hovedkvarteret, er der tale om en kortfattet to siders liste med åbne spørgsmål om, hvordan projektet skrider frem. ${ }^{6}$ Ideen var ikke, at medarbejderne skulle besvare spørgsmålene individuelt, men at de skulle mødes med jævne mellemrum og diskutere de spørgsmål, der gav mening. Planen var, at dette skulle institutionalisere den ,uformelle feedback“, som også vægtes højt i de internationale guidelines, men uden at denne feedback ville komme til at udgøre ekstra bureaukrati. Hanne, som var en de få medarbejdere, der også arbejdede i organisationen, da systemet sidst blev anvendt, beskriver her dets fordele:

Det var et godt system at have på grund af den kommunikation, det skabte. Det tvang os til at formulere nogle klare mål, og det tvang os til at arbejde sammen på tværs. Det gav arbejdsglæde, og der var virkelig diskussionslyst. Det var en glad periode (interview med NatureAid-medarbejder 2011).

Gruppens genopfundne, hjemmelavede standard skulle altså skabe et fælles rum for diskussioner af indhold og fremdrift i udviklingsarbejdet. Efter medarbejdernes mening kunne det store potentiale, som de vitterligt anså monitorering og evaluering for at have, lettere manifestere sig, hvis disse aktiviteter blev foretaget kollektivt i stedet for på individuelle kontorer, og hvis deres indhold blev konkretiseret og reduceret snarere end abstraheret og ekspanderet.

\section{Kritiske potentialer?}

Ovenfor har vi kort skitseret to evalueringsredskaber, der hver især har forskellige kendetegn: et internationalt/eksisterende/formelt sanktioneret over for et lokalt/ underudviklet/hjemmelavet. Det genopfundne, hjemmelavede redskab nåede ikke 
at blive taget $\mathrm{i}$ brug $\mathrm{i}$ feltarbejdsperioden, så følgende overvejelser er baseret på de diskussioner, der foregik i gruppen om evalueringens slagsider og potentialer.

Det var ikke en ubetydelig ekstra opgave, medarbejderne påtog sig ved at bakke op om genoplivelsen af det gamle system. Organisationens arbejde dækker mange forskellige aspekter af bæredygtighed og socioøkonomisk udvikling, og det kræver en stor indsats at håndtere projekter og afrapportere igennem de formelle systemer. Der er ikke megen tid til overs, og den, der er, kunne sagtens bruges på andre ting end at udvikle en ny standard. Men selv om tidspres var et tilbagevendende tema i vore samtaler, arbejdede konsulenterne altså alligevel ihærdigt på at beskrive alternative evalueringsprocedurer og på at overbevise ledelsen om, at deres system burde have en legitim plads blandt organisationens procedurer og processer.

Måske kan vi sige, at forskellen på det eksterne og interne evalueringssystem er, at det første definerer en verden, der fordrer, at konsulenterne foretager specifikke målinger, mens konstruktionen af det andet indebærer, at de selv definerer den verden, inden for hvilken de ønsker at måle. Ikke desto mindre rejser deres interesse for at have en lokal standard spørgsmål. Hvorfor ønsker disse mennesker at udvikle endnu en standard, når de allerede har rigeligt at gøre og egentlig ville foretrække at være mere til stede i deres projekter rundtomkring i verden? Dette spørgsmål åbner op for en diskussion af antropologiens kritiske potentialer i mødet med optimering, som den finder sted i praksis.

Forskellige kritiske perspektiver tilbyder svar på spørgsmålet om, hvorfor medarbejderne giver sig i kast med at udvikle nye metrikker. Med inspiration fra Bourdieu eller en vis læsning af Foucault kan der argumenteres for, at medarbejderne har internaliseret en logik, der ikke giver mulighed for at tænke uden for evalueringsparadigmet. Evalueringsparadigmet definerer et særligt socialt rum, hvor evalueringen foregår, og da evalueringens logik er internaliseret (som habitus), har aktørerne grundlæggende svært ved at udfordre systemet.

Følger man sådanne tilgange, kunne medarbejdernes arbejde med at genopfinde standarden siges at illustrere, at de er underlagt evalueringsparadigmets sprogspil. De har simpelthen ikke adgang til nogen anden referenceramme til brug for selvrefleksion og intern læring end den, der tilbydes af evalueringerne. Derfor er det kun muligt for dem at tolke deres arbejde gennem synliggørelse af effekter. Det er således ingen overraskelse, at outcome er et ofte anvendt ord i organisationen. Som filosoffen Jean-Francois Lyotard skrev i Viden og det postmoderne samfund (1979) bliver „bevisførelse" performativ i informationsalderen. Det vil sige, at bevisførelsen skal leve op til bestemte formmæssige krav, og at ,det tekniske [formmæssige, æstetiske] kriterium [...] [ikke] forbliver [...] uden indflydelse på sandhedskriteriet“ (op.cit.91). Og dermed bliver evalueringerne i stigende grad selvreferentielle. 
Procedurernes evne til at præstere i forhold til deres egen form erstatter deres evne til at udtale sig om arbejdets substans. Form overtager indhold. På netop dette punkt var Lyotard inspireret af sociologen Niklas Luhmanns sociale systemteori. Og selv om hverken Lyotard eller Luhmann er de mest citerede i antropologiske kredse, kan deres perspektiv på selvreferentiel evaluering også findes der.

I sit bidrag til antologien Audit Cultures argumenterer antropologen Peter Pels eksempelvis for, at evalueringsparadigmet ,aktivt konstruerer de miljøer, det opererer inden for, og gør dem mere 'evaluerbare', samtidig med at det former sig selv som ufejlbarligt" (Pels 2000:142). I denne beskrivelse bliver monitorerings- og evalueringsaktiviteter netop performative, idet de definerer den verden, de virker inden for. Men fordi det er (i princippet uforanderlige) standarder og procedurer, der bestemmer, hvori verdens elementer består, og hvad deres relevans er, lukker systemet sig om sig selv. Det bliver blindt over for egne fejl og mangler. Et hvilket som helst evalueringsproblem påkalder simpelthen flere og grundigere evalueringer. Selve evalueringsaktiviteten usynliggøres i denne proces, og derved bliver paradigmet selv usårligt.

Der er dog ikke noget i vores materiale, der peger på evalueringernes usårlighed. Som nævnt var det tværtimod standardernes skrøbelighed og irrelevans, der frustrerede vore informanter. Det var disse standarders manglende evne til at gøre noget som helst andet end at hobe sig op i skuffer og skabe, der ansporede deres forsøg på at udføre monitorering på nye måder. Der er heller ikke noget, der peger på, at medarbejderne ukritisk tog det eksisterende evalueringssprog til sig i arbejdet med den nye standard. Faktisk illustrerede en del af dette arbejde snarere en mangel på interesse for det eksisterende system.

Medarbejderne i NatureAid er således ikke naive i forhold til standardernes manglende evne til at indfange virkeligheden $i$ al dens kompleksitet. De er bevidste om, at standarder kun formår at forholde sig til det, de er skabt til at måle og veje. Når de bruger tid på at genopfinde en standard, er det, fordi de gerne vil vide noget andet om igangværende og afsluttede projekter. De har ingen ambition om at vide ,det hele“, men ønsker derimod at begrænse verdens kompleksitet på relevante måder. Det er muligvis netop, fordi miljøorganisationens internationale standarder er designet til at indfange alle stadier i en projektcyklus og derfor rummer et væld af både kvalitative og kvantitative indikatorer, at den ikke er i brug i den danske afdeling. Standardens evne til at indkapsle alle mulige og umulige dimensioner af arbejdet er altså ikke et positivt træk for medarbejderne. For hvad er fornuften i en standard, der ikke tillader en effektiv afgrænsning af kontekst? I stedet udvikler de et redskab, der skal hjælpe dem med at foretage specifikke reduktioner af kompleksitet og dermed begrcense omfanget af den virkelighed, der skal håndteres. 
Man kan da måske formode, at vore informanters ønske om at skabe en minimal og „reduktiv standard“ hænger sammen med en magtproblematik. Ved at reducere projekternes kompleksitet til nogle få parametre kan de bedre kontrollere projekterne (og deres partnere i forskellige udviklingslande). De benytter den samme slags reduktive informationspolitik, som donorerne benytter over for dem, blot i en mindre skala. Der er imidlertid ikke noget, der tyder på, at vore informanter har nogen planer om at benytte deres standard til kontrol, hverken af sig selv, hinanden eller deres partnere. Tværtimod var konsulenterne vedholdende kritiske over for de eksterne standarders firkantede målinger, der netop virkede for kontrollerende og derfor modarbejdede konsulenternes oprigtige forsøg på at skabe ligeværdige partnerskaber med folk og organisationer i Asien og Afrika. Ligeledes er der ikke noget i vores etnografiske materiale, der indikerer, at der er tale om „,dobbelt bogføring“, eller at de har nogen forhåbning om at undergrave de internationale standarder.

Fælles for de kritiske analyseformer, vi her har skitseret, er, at de kun giver mening, hvis en række af informanternes eksplicitte udsagn ignoreres eller ikke tages for gode varer. Det er muligt, at vi ikke kan acceptere, at den standard, der forsøges genimplementeret i organisationen, vil kunne skabe et åbent, refleksivt rum (a la Habermas), hvor viden frit kan udveksles, men det er ikke etnografisk forsvarligt at ignorere betydningen af dette ideal. Mens der næppe er nogen tvivl om, at miljøkonsulenterne bliver „subjektiveret“ af standarderne (Foucault 1991), er det derfor helt centralt at skelne mellem subjektivering som en proces, hvorigennem folk tvinges til betingelsesløst at overgive sig til standarder, og subjektivering forstået som det at acceptere visse afgrænsninger, der samtidig giver nye handlemuligheder (Gomart \& Hennion 1999).

\section{Gode standarder afgrænser virkeligheden}

Hvad gør en standard god? For vore informanter har en god standard ikke til formål at muliggøre en mere omfattende kontrol med udviklingsprojekter. De postulerer heller ikke, at den kan eller skal afdække hele virkeligheden: Det er blandt andet derfor, den uproblematisk kan sameksistere med en allerede eksisterende standard. Kodeordet er sameksistens snarere end „bricolage“, for der er heller ikke tale om en kreativ sammenføjning af standarderne. De skal simpelthen leve parallelt og gøre forskellige ting.

En god standard skal altså ikke repræsentere verden i al dens kompleksitet. I stedet skal den kunne beskære. En standard skal lade de ting fremkomme, som miljøkonsulenterne ønsker at kunne evaluere på, og den skal samtidig forhindre, at bestemte ting tvinges frem i lyset. Således kan vi se, at ambitionen med vore 
konsulenters standard er, at den skal fungere som en „gavmild begrænsning“ (Gomart 2004) af verden. Konsulenterne er ganske villige til at underlægge sig en sådan standards krav, selv om de ved, at den vil mindske deres syns- og handlerum, for det er netop beskæringen, der gør det muligt for dem at arbejde fokuseret. Af samme årsag kan antropologiens analytiske potentiale ikke bero på en kritik af standarders reduktion af kompleksitet, for reduktion er gode standarders eksplicitte og refleksive formål.

Lad os fastholde denne pointe lidt endnu. Antropologer overraskes ikke længere, når de hører, at formelle systemer og standarder medfører dekontekstualisering. Lokale fortolkninger og handlemønstre, politiske overvejelser under bordet og usynlige økonomiske incitamenter forsvinder, når de oversættes til evalueringers nøgterne sprog. Men miljøkonsulenterne overraskes heller ikke af evalueringers politiske karakter. De er udmærket klar over, at evalueringer indgår i uregerlige interaktioner, hvor deres rolle er at skabe sammenhæng mellem agendaer og forhåbninger, der stort set ikke har nogen berøringsflade - om end de ville udtrykke sig om dette på en anden måde (Rottenburg 2009). Det er, fordi ulandsteamet forholder sig til evalueringens potentielt politiske effekter i mindst lige så høj grad som kritiske antropologer, at de involverer sig $i$ at specificere alternative evalueringsformer.

Antropologens job og lidenskab er ikke på samme måde som udviklingsarbejderens afhængig af konstant refleksion over forbindelsen mellem evalueringer og det, der evalueres. Imidlertid har antropologen og udviklingspraktikeren det til fælles, at deres ekspertise, på hver sin måde, er defineret ved at kunne beskrive en praksis og reflektere over den. Mens udviklingspraktikerens ekspertise er defineret ved en evne til at kunne gennemføre ,de samme“ projekter i forskellige kontekster, er antropologiens ekspertise defineret ved at finde forskellige former for kompleksitet i forskellige kontekster Hverken den ene eller den anden slags ekspertise er neutral, og som Cooper og Packard (1997:26) påpeger, kan begge slags ekspertise benyttes til såvel analytisk og praktisk arbejde som til selvretfærdig kritik af andre.

Da det imidlertid er bemærkelsesværdigt, i hvor høj grad vore informanter er optaget af begge dele (både kompleksitet og standardisering/gentagelse), kunne kritiske samfundsforskere måske loere noget af dem. Frem for en ureflekteret underkastelse ser vi derfor udviklingsarbejdernes arbejde med nye standarder som en eksperimentel respons, ét ud af en række forsøg på at håndtere det komplekse sæt af praktiske, politiske og „epistemologiske bekymringer“ (Stoler 2010), der er en integreret del af deres job. 


\section{Synligheden og dens „anden“}

Lad os endnu en gang kigge på miljøorganisationen og medarbejdernes (ekstra)arbejde med at etablere en alternativ evalueringsmodel. De internationale standarder fordrer, at medarbejderne frembringer information, de ikke opfatter som relevant for deres eget arbejde. Ikke desto mindre får denne information sit eget liv, når den først er frembragt. Den skaber specifikke former for gennemsigtighed, og de aktiviteter, der gøres gennemsigtige, gøres til genstand for yderligere intervention og observation. Mens medarbejderne således påtvinges at konstruere en form for gennemsigtighed og dermed også underlægger deres partnere det samme synlighedsregime, definerer deres egen standard en anden form for synlighed. Forhåbningen til den hjemmelavede standard er, at den vil skabe en form for gensidig synlighed, der styrker medarbejdernes mulighed for at kommunikere om deres arbejde på en måde, der gavner såvel fælles læring som de enkelte projekter.

Mens de internationale standarder lægger op til, at det er godt og nyttigt at beskrive virkeligheden så detaljeret som muligt, søger medarbejderne at etablere nogle redskaber, der kan hjælpe dem til at indkredse andre områder. Det hæmmer dem at skulle arbejde med en standard, der godt nok er international og certificeret, men som ikke desto mindre er designet til specifikt at evaluere aktiviteter $\mathrm{i}$ forhold til deres effekt på naturbevarelse. Naturbevarelse er ganske vist vigtigt for NatureAid, men filosofien på det danske kontor er, at det er et mål, der bedst kan nås ved en integreret indsats, der i lige så høj grad koncentrerer sig om social og økonomisk udvikling. De har brug for et redskab til at tilvejebringe forskellige informationer, der alle har meget specifikke formål: at give afdelingslederen „overblik over programmerne“, at skabe mulighed for at lave relevante teams, at ,lave en jævnlig opdatering på, hvor langt vi er kommet", at give de faglige medarbejdere ,et redskab, der kan gå tilbage og se, hvad var indikatorerne, hvad er outcome“, at „formulere nogle klare mål“" og, ikke mindst, at skabe diskussionslyst og (sam)arbejdsglæde. Den lokale standard udtrykker altså både en vis modstand mod at blive kontrolleret fra hovedkvarteret i Geneve og et ønske om at styrke lokale kompetencer. Forskellene mellem disse standarder angiver, at optimering iscenesættes og finder sted på vidt forskellige måder i organisationen.

I foråret 2011 rejste Winthereik til Vietnam med to miljøkonsulenter. Det primære formål med rejsen var at foretage en midtvejsevaluering af et økoturismeprojekt i en nationalpark i det sydlige Vietnam. Det involverede også et besøg i NatureAids lokale hovedkontor i Hanoi, der havde til formål at briefe om igangværende aktiviteter og at lægge fremadrettede planer. Dette besøg udkrystalliserede de forskelle i optimeringsstrategier, vi netop har beskrevet. 
I Hanoi holdt en af konsulenterne, Erik, et møde med den nyudnævnte chef for det regionale udviklingsprograms monitorerings- og evalueringsenhed. Chefen var en mand med store visioner for, hvordan monitorering kunne styrke organisationens evne til at styre og lede egne aktiviteter. Under mødet beskrev han, hvorledes opsamlingen af mere information om individuelle projekter ville gøre det nemmere for det regionale program at nå dets overordnede målsætninger. Blandt andet præsenterede han en omfattende plan for, hvordan NatureAid kunne komme til at kvantificere alt fra biodiversitet til projektfremdrift. Et middel var at skabe „biodiversity trackers“. Målet var, at alle organisationens aftagergrupper skulle forbindes $i$ et sammenhængende, kybernetisk system.

I første omgang var Erik både imponeret og noget overvældet af denne vision. Men da kontorchefen projicerede et gigantisk regneark med 1.700 indikatorer op på mødelokalets væg, genvandt han fatningen. Konfronteret med dette regneark begyndte Erik at stille spørgsmål ved fornuften i det enorme indikatorsystem. Han spurgte, hvordan det ville hjælpe hans konkrete forsøg på at udføre en form for styring og projektledelse (adaptive project management), hvor alle beslutninger i princippet tages i samarbejde med lokale partnere, således at ejerskab langsomt kan overdrages til dem. Han konfronterede kontorchefen med et scenarie, hvor samarbejdet med de mange eksterne partnere, der ikke kunne antages at være interesseret $i$ at levere store mængder data til NatureAids system, ville lide skade på grund af mængden af indikatorer.

Fra et ledelsesperspektiv forekom systemet at være ideelt til at optimere NatureAids arbejde. For Erik stod det imidlertid klart, at en sådan indikatoreksplosion ville øge kompleksiteten og ikke blot være unyttig, men direkte skadelig for forholdet til partnerne. Hans idé om optimering handlede derimod om, at partnere skulle sikres indflydelse. Erik udtrykte dette procesorienterede perspektiv i en formulering, der blev brugt så ofte, at det nærmest blev et slogan: „Vi skal sætte en udvikling i gang.“ At sætte en udvikling i gang betød inddragelse. Og denne inddragelse ville lide skade, hvis den blev underlagt det enorme system af indikatorer. Samtidig tvivlede han på, om disse indikatorer faktisk ville kunne måle inddragelse på en relevant måde.

Feltarbejdet i det danske NatureAid-kontor og diskussionen mellem Erik og monitorerings- og evalueringseksperten viser, at gennemsigtighed ikke i sig selv er gennemsigtig. Forsøg på at skabe gennemsigtighed varierer dramatisk, selv inden for NatureAid. Forskellen er ikke kun mellem Hanoi og danske konsulenter, for den minder om diskussioner, der foregår internt i København. Her har den lokale ledelse visioner for monitorering og evaluering, der overordnet set er i tråd med de „1.700 indikatorers“ strategi. Det er medarbejderne, ikke ledelsen, der søger mere fleksible måder at optimere på. 
I sit kapitel „The Tyranny of Transparency“ stiller Strathern spørgsmålet: „Hvad skjuler gennemsigtighed?" (Strathern 2000a:60). Hendes svar falder i to dele. Første del diskuterer det forhold, at tilliden til store mængder af data usynliggør den tillid, der er nødvendig for, at en organisation kan fungere (og således også producere denne datamængde). I anden del forholder hun sig imidlertid kritisk til det første svar. En kritisk analyse, hvis potentiale ligger i at demonstrere, at evalueringer ikke beskriver virkeligheden, som den virkelig er, bunder i en fundamental misforståelse af relationen mellem verden og de kategorier, igennem hvilke den beskrives og afgrænses. Der er ingen beskrivelser, der viser den „virkelige virkelighed“, for alle virkeligheder er beskårede (Walford 2013). Det relevante spørgsmål handler derfor om, hvilke principper og metoder beskæringen beror på.

I modsætning til mange kritikere af evalueringsparadigmet ser Strathern ingen principielle barrierer for, at uformelle eller „bløde“ aspekter af organisatoriske virkeligheder kan indfanges gennem evalueringer. Som vi har set, er det på nuværende tidspunkt faktisk et eksplicit krav at sådanne aspekter skal indfanges af NatureAid (jf. den internationale standard). Problemet er derimod, at når specifikke informationer er ,ude i det fri“, medfører det uafvendeligt, at de også må tages alvorligt. Medarbejderne bliver nødt til at acceptere dem som relevant viden, der kan få konsekvenser. Og disse konsekvenser er svære at komme af med igen. Det er sjældent muligt at spole tilbage til tiden inden evalueringen, selv hvis dens effekter viser sig at være uhensigtsmæssige. Deri, siger Strathern, ligger evalueringens virkelige forbandelse og gennemsigtighedens tyranni. Når miljøkonsulenterne udvikler lokale standarder, der indeholder hjemmelavede begrænsninger, som opleves som „gavmilde“, er det således et forsøg på at afværge tyranniet ved at tilvejebringe viden, hvis præmis for gennemsigtighed er forskellig fra det officielle systems.

Gennemsigtighed skjuler imidlertid endnu mere, end hvad Strathern påpeger. For det første skjuler ideen om gennemsigtighed - næsten altid formuleret i ental - at gennemsigtighed tager mange former. Vi bør tale om gennemsigtigheder, og alle gennemsigtigheder definerer deres egne former for „ukrudt“ (Tsing 2005: 171-205; Jensen \& Winthereik 2013:93-121) i form af uregerlige randområder, de ikke er i stand til at forholde sig til. Optimering selv er ligeledes en mangetydig størrelse, der dækker over forskelligartede hensigter, ambitioner og aktiviteter. Selv inden for rammerne af NatureAids lille danske kontorlandskab tager optimeringen forskellige udtryksformer.

Disse udtryksformer kan ramle sammen og skabe kontroverser og frustrationer i samarbejdet mellem NatureAid i Danmark og det internationale hovedkvarter eller i samarbejdet med Danida eller andre partnere. Det, der virker som en 
indlysende strategi til at skabe gennemsigtighed fra ét perspektiv, kan fremstå ganske uforståeligt og uigennemsigtigt fra et andet. Som vi har set, skaber de internationale standarders beskæring af verden eksempelvis ikke overblik og orden for de danske miljøarbejdere. Den skaber snarere rod og stress. Omvendt medfører den reduktion af verdens kompleksitet, som de selv ønsker at forestå, ingen gennemsigtighed fra ledelsens perspektiv: De ser den slet ikke, for den falder uden for rammerne af deres forståelse af det gennemsigtige. Optimeringens gennemsigtighed beror således altid på en implicit definition af, hvori verdens ukrudt består, og der er altid usammenhængende eller modstridende definitioner på spil.

\section{Postkritiske optimeringer}

Et tilbagevendende tema i dette bidrag har været at beskrive begrænsningerne i den kritiske samfundsteoris møde med optimering efter new public management. Ved hjælp af en analogi mellem praksis i NatureAids danske kontor og antropologisk begrebsliggørelse og analyse har vi forsøgt at vise, hvordan den kritiske teori ofte tager udgangspunkt i en dualisme mellem en „,bundlinje“" og så ,alt det andet“, der ikke kan måles. Denne præmis beskrives af litteraturteoretikeren Barbara Herrnstein Smith i hendes kapitel „The Critiques of Utility“:

Oppositionen mellem værdidiskurser er muligvis mest tydelig i de tilbagevendende kampe mellem to slags beregning [...]: på den ene side [...] en, der har til formål at nå til en specifik og veldefinerbar 'bundlinje' (ofte, men ikke nødvendigvis, økonomisk) på den mest effektive måde, og på den anden side, og typisk i en fjendtlig relation til den første, en anden beregning, der ikke navngives som sådan, der typisk fokuserer på og promoverer netop de ting, der blev ignoreret af den første (Smith 1988:133).

Den kritiske antropologis mandat falder inden for, hvad Smith kalder, den anden slags beregning, hvis mandat netop er at påvise alle de ,subtile, diffuse [...] og heterogene“ (ibid.) aspekter, der fremtræder, når antropologen studerer komplekse sociale kontekster. Dette er baggrunden for dens tilbagevendende kritik af reduktion. Når Smith beskriver begge disse former for diskurs om værdi som beregninger, er hendes pointe imidlertid, at det er en fejl at antage, at de er væsensforskellige. Der forefindes ikke noget normativt hierarki, der abstrakt kan diktere, at reduktion til en bundlinje er forkasteligt, hvorimod formidling af kompleksitet er forbilledligt. „Disse kategorier, de overvejelser de giver sig af med, og de operationer, de udfører, kan kun skelnes relativt og lokalt fra hinanden“, skriver Smith (ibid.). Der er simpelthen tale om forskellige kalkuler 
af vigtighed (se også Helgesson \& Muniesa 2013). Denne symmetriske indstilling er central for en postkritisk antropologi. Den er præmissen for at tilgå forskellige optimeringsprojekter med en fornyet empirisme.

Stratherns (2000) bud på antropologiens rolle i et evalueringssamfund er, at den bør undersøge evalueringer som kulturelle praksisser, der afgrænser virkeligheden på bestemte måder. Antropologer beskriver ikke neutralt, hvordan andre beskærer virkeligheden i forsøget på at optimere den, og der er ikke noget metaperspektiv, hvorfra man kan sige, at deres analyser er bedre (eller dårligere) end andres. Men fordi deres kalkuler af værdi og relevans ofte er forskellige fra andres, bliver de medskabere af distinkte former for (viden om) virkeligheder.

Stratherns sammenligning af evaluatorens og antropologens kalkuler hæfter sig særligt ved én bestemt forskel. Hvor de informationer, som evalueringer bringer frem i lyset, har sveert ved at forsvinde igen (de vedbliver at fremstå gennemsigtige), er antropologiens kalkule baseret på, at etnografiske data er flygtige anordninger (transient devices), der kan bruges, sættes lidt i baggrunden, for måske at trækkes frem igen ved en anden lejlighed.

Evalueringsdata postulerer at være neutrale, og det hjælper til at give dem stabilitet og rækkevidde ud over deres egen kontekst. I modsætning dertil kan den etnografiske beskrivelse nok opnå en vis autoritet i bestemte sammenhænge, men kun for så vidt som den analytiske kontekst forbliver synlig. Den etnografiske beskrivelses iboende flygtighed fordrer derfor, at antropologen altid må eksplicitere, hvilket argument den præcist er en ressource for. Ligeledes er antropologiens kalkuler, i modsætning til evalueringens, baseret på vigtigheden af at lave argumentet. Det etnografiske udskæringsarbejde (skabelsen af argumentet) begrunder den flygtige beskrivelse, der måske kan tages frem igen ved en anden lejlighed og bygges videre ind i et andet argument. Disse muligheder strækker sig ud over den akademiske kontekst, for de etnografiske udskæringer kan også bidrage til skabelsen af nye former for offentlighed (Schick \& Winthereik 2013).

Her har vores beskrivelse fokuseret på skabelsen af standarder, som medarbejderne i NatureAids danske afdeling håber vil være brugbare for deres fremtidige arbejde. For at forstå dette behov har vi dokumenteret en række af evalueringernes ,produktionsforhold“. Vi har også tilstræbt at synliggøre en ellers usynlig del af evalueringsarbejdet - nemlig dens relation til antropologiens vidensproduktion.

For den kritiske læser er dette muligvis ikke tilstrækkeligt. Hvad med muligheden for at placere miljøarbejdet i en „større kontekst“ som eksempelvis globalisering eller neoliberalisme? Hvordan kan vi hævde at diskutere udviklingsarbejdets optimering, når vi negligerer makropolitiske og økonomiske forhold? Vi vil på 
ingen måde benægte vigtigheden af at studere sådanne bredere fænomener (så længe de ikke har en på forhånd defineret kritisk indstilling som præmis). Enhver situation indeholder langt flere antropologiske dimensioner, end nogen beskrivelse kan gabe over.

Vores centrale etnografiske observation har imidlertid været medarbejdernes vedholdende refleksioner over, hvordan de bedst muligt kunne udføre deres monitorerings- og evalueringsarbejde, givet at dette arbejde skal sammenbinde partnere så forskellige som Danidas evalueringskontor og landsbyboere i Vietnam. Disse miljøkonsulenter udfører et konstant kreativt og komparativt optimeringsarbejde. De forsøger at justere de formelle evalueringer for at gøre dem en tand mere fleksible og brugbare. De afprøver nye samarbejdsformer med deres partnere, og, som vi har beskrevet, de eksperimenterer også med genopfindelsen af deres egen standard. De gør alle disse ting, fordi de er klar over, at den verden, de opererer i, er kompleks, men ikke for at tillade hele verdens kompleksitet at udfolde sig i deres arbejde. Hvis de gjorde det, ville deres projekter falde sammen så hurtigt som et korthus i blæsevejr.

Vi kan specificere en sidste kontrast, der forekommer os central. Denne kontrast relaterer til forskellen mellem optimering som et normativt krav og som en eksperimentel indstilling. Der er ingen tvivl om, at normative optimeringsagendaer er tilstedeværende i NatureAid, og at de påkræver sig megen opmærksomhed. Ikke desto mindre vil vi hævde, at organisationens konkrete og praktiske fremdrift eksemplificeret ved deres succesfulde projekter - langt hen ad vejen er resultatet af konsulenternes løbende optimeringseksperimenter. Betegnelsen eksperimenter er på sin plads, fordi disse former for optimering har som præmis, at de skal bevæge sig ind i nye territorier.

Konsulenterne ved nemlig sjældent, hvad der vil virke i samarbejdet med nye partnere, eller hvordan disse interaktioner kan sammenbindes i projekter, der også skal leve op til forskelligartede formelle krav. Deres forsøg på at optimere chancerne for gode resultater indebærer derfor risikoen ved at navigere ind $\mathrm{i}$ ukendt farvand. Risikoen er blandt andet, at deres eget hjerteblod og deres egen drivkraft - deres forskellige forsøg på at skabe en bedre verden - udvandes eller oversættes til uigenkendelighed i mødet med alle disse fremmedartede krav og agendaer. Ikke desto mindre er der ikke noget alternativ, hvis de vil opnå succes, og derfor må de nødvendigvis løbe risikoen ved at indgå i sådanne eksperimenter.

Her kan vi drage en sidste parallel mellem miljøkonsulenternes optimeringsarbejde og antropologisk praksis. Antropologer og andre samfundsforskere mødes også i stigende grad med krav om at demonstrere den praktiske, samfundsmæssige eller erhvervsrettede brugbarhed af deres egen vidensproduktion. Der er ikke noget principielt forfærdeligt ved denne udvikling - den illustrerer simpelthen, at der er 
mange værdikalkuler på spil i forhold til humanistisk og samfundsvidenskabelig forskning. Faren opstår i det øjeblik, antropologer begynder at opgive deres egne, situerede værdikalkuler og sætter alt ind på at leve op til specifikke forestillinger om optimering, der hævder at være universelle.

Miljøkonsulenternes svar på de indikatorbaserede optimeringskrav, der omgiver dem, er genopfindelsen af deres egne standarder. Deres arbejde kan ses som et praktisk, alternativt perspektiv på kritisk teori (jf. Smith 1988). Med disse alternative perspektivers potentialer i tankerne er det relevant at overveje, hvilke optimeringsprojekter antropologer selv er i stand til at forestille sig og villige til at indtræde $\mathrm{i}$.

\section{Noter}

1. Dermed ikke sagt, at NPM er et altomfattende paradigme, der ikke kan gøres modstand mod eller „,arbejdes rundt om“. Se Neyland (2008) for en diskussion af forskelle, ligheder og grænseflader mellem etnografi om og etnografi for organisationer.

2. Alle navne er anonymiserede.

3. Aftalen, som er ratificeret under OECD's agentur for udvikling (DAC), går under navnet Paris-erklæringen og handler om at gennemføre fem principper: lokalt ejerskab til udviklingsaktiviteter, strømligning af udviklingsindsatsen, harmonisering af mål, monitorering af resultater og gensidig ansvarlighed mellem donorlande og modtagere http://www.oecd.org/ dac/effectiveness/parisdeclarationandaccraagendaforaction.htm.

4. I tråd med dette påpeger en rapport fra HLM Consult (2008), at medarbejdere i udviklingssektoren vægter forbedring (improving) over dokumentation (proving).

5. Alle oversættelser er vore egne.

6. Se Mol og Law (2002:13-14) for en diskussion af listers egnethed til at rumme kompleks viden.

Søgeord: monitorering og evaluering, transparens, NGO-arbejde, videnskabs- og teknologistudier (STS), postkritisk antropologi

\section{Litteratur}

Bowker, Geofrey C. \& Susan Leigh Star

2000 Sorting Things Out. Classification and its Consequences. Cambridge, MA: MIT Press.

Cooper, Frederick \& Randall M. Packard

1997 International Development Aid and the Social Sciences. Berkeley \& Los Angeles: University of California Press.

Dalsgaard, Steffen \& Morten Nielsen

2013 Introduction. Time and the Field. Social Analysis 57(1):1-19. 
Foucault, Michel

1991 Discipline and Punish. Birth of the Prison. London: Penguin.

Gomart, Emilie

2004 Surprised by Methadone. In Praise of Drug Substitution Treatment. Body and Society 10:85-110.

Gomart, Emilie \& Antoine Hennion

1999 A Sociology of Attachment. Music, Amateurs, Drug Users. In: J. Law (ed.): ActorNetwork Theory and After. Pp. 121-47. Oxford: Blackwell Publishers.

Helgesson, Claes-Fredrik \& Fabian Muniesa

2013 For What It's Worth. An Introduction to Valuation Studies. Valuation Studies 1(1): $1-10$.

HLM Consult

2008 Mapping of Monitoring and Evaluation Practices of Danish NGOs. Evaluation Report Commissioned by the Danish Ministry of Foreign Affairs, Department of Evaluation. København: Danida.

Jensen, Casper Bruun \& Brit Ross Winthereik

2013 Monitoring Movements in Development Aid. Recursive Partnerships and Infrastructures. Cambridge, MA: MIT Press.

Latour, Bruno

2004 Why has Critique Run Out of Steam? From Matters of Fact to Matters of Concern. Critical Inquiry 30(2):225-48.

Lave, Jean \& Etienne Wenger

$1991 \quad$ Situated Learning. Legitimate Peripheral Participation. Cambridge: Cambridge University Press.

Lyotard, Jean-Francois

$1979 \quad$ Viden og det postmoderne samfund. Aarhus: Slagmark.

Mol, Annemarie \& John Law

2002 Complexities. An introduction. In: J. Law \& A. Mol (eds): Complexities. Social Studies of Knowledge Practices. Pp. 1-23. Durham, NC, \& London: Duke University Press.

Neyland, Daniel

2008 Organizational Ethnography. London: Sage.

Pedersen, Morten Axel \& Morten Nielsen

2013 Trans-temporal Hinges. Reflections on an Ethnographic Study of Chinese Infrastructural Projects in Mozambique and Mongolia. Social Analysis 57(1):12242 .

Pels, Peter

2000

The Trickster's Dilemma. Ethic and the Technologies of the Anthropological Self. In: M. Strathern (ed.): Audit Cultures. Anthropological Studies in Accountability, Ethics, and the Academy. Pp. 135-72. London \& New York: Routledge.

Power, Michael

1997 The Audit Society. Rituals of Verification. Oxford: Clarendon.

Rottenburg, Richard

2009 Far-fetched Facts. A Parable of Aid. Cambridge, MA: MIT Press. 
Schick, Lea \& Brit Ross Winthereik

2013 Innovating Relations. Or Why Smart Grid is not too Complex for the Public. Science and Technology Studies 26(3):82-102.

Shore, Cris \& Susan Wright (eds)

1997 Anthropology of Policy. Critical Perspectives. London: Routledge.

Smith, Barbara Herrnstein

1988 Contingencies of Value. Alternative Perspectives for Critical Theory.

Cambridge, MA: Harvard University Press.

Stoler, Ann Laura

2010 Along the Archival Grain. Epistemic Anxieties and Colonial Common Sense. Princeton, NJ: Princeton University Press.

Strathern, Marilyn (ed.)

2000 Audit Cultures. Anthropological Studies in Accountability, Ethics, and the Academy. London \& New York: Routledge.

Strathern, Marilyn

2000a The Tyranny of Transparency. In: H. Nowotny \& M. Weiss (eds): Shifting Boundaries of the Real. Making the Invisible Visible. Pp. 59-78. Zürich: VDF Verlag.

Tsing, Anna

2005 Friction. An Ethnography of Global Connection. Princeton, NJ: Princeton University Press.

Vikkelsø, Signe \& Sidsel Vinge

2004 Introduktion. I: S. Vikkelsø \& S. Vinge (red.): Hverdagens arbejde og organisering i sundhedsvæsenet. Side 11-21. København: Handelshøjskolens Forlag.

Walford, Antonia Caitlin

2013 Transforming Data. An Ethnography of Scientific Data from the Brazilian Amazon. Ph.d.-afhandling, IT Universitetet i København, Danmark. 